\title{
Bovine landscape genetics in Brazil
}

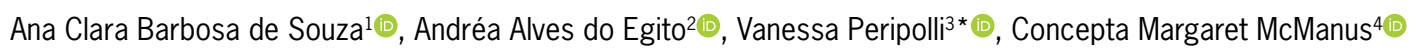

Universidade de Brasilia/Faculdade de Agronomia e Medicina Veterinária, Campus Universitário Darcy Ribeiro 70910-900 - Brasília, DF - Brasil.

2Embrapa Gado de Corte, Av. Rádio Maia, 830 - 79106-550

- Campo Grande, MS - Brasil.

${ }^{3}$ Instituto Federal Catarinense, Campus Araquari, Rod. BR

280, km 27 - 89245-000 - Araquari, SC - Brasil.

4Universidade de Brasília/Instituto de Biologia, Campus Universitário Darcy Ribeiro - 70910-900 - Brasília, DF Brasil.

*Corresponding author < vanessa.peripolli@hotmail.com>

Edited by: Gerson Barreto Mourão

Received May 20, 2020

Accepted September 16, 2020
ABSTRACT: The aim of this study was to explore spatial genetic structure patterns in cattle breeds adapted to local conditions in Brazil. We georeferenced 876 animals of ten breeds raised in Brazil kept in the Genebank of Brazilian Agricultural Research Corporation (Embrapa) by sample locations using the QGIS 2.4.0 software. The Mantel tests, spatial autocorrelation, and Monmonier tests were performed. The distances for spatial correlation tests ranged from 5 to 15 classes. The results indicated genetic discontinuities in cattle breeds from the Midwest, South, and Southeast of the country. Correlation between genetic and geographic distance was low, but significant. The Monmonier Maximum Distance Algorithm indicated an initial subdivision of Curraleiro and then Pantaneiro from the other breeds. In another subdivision, Criollo, Mocho Nacional, and Caracu were grouped. Genetic discontinuity was observed beyond $431 \mathrm{~km}$, the minimum sampling distance between populations for conservation purposes.

Keywords: cattle, genetic landscape shape, georeference, spatial correlation

\section{Introduction}

The relationship between species adaptation and landscape characteristics has led to the emergence of "landscape genetics", a research line that combines knowledge of population genetics, landscape ecology, and spatial statistics (Fenderson et al., 2020; Storfer et al., 2010) with the objective to describe and explain how the landscape and its components affect the genetic variation of populations of animals and plants.

Farmers empirically attempt to eliminate or control external factors that negatively affect agricultural production (Antonini and Argilés-Bosch, 2017), such as environmental factors (vegetation, soil, climate and geomorphology). Farmers make use of the knowledge of local environmental controls, such as climatic characteristics (air temperature and humidity) and altitude (Costa et al., 2014), to implement and establish production systems (Joost et al., 2010).

In this sense, the application of correct and modern information and technological research that provide the understanding and control of physical factors could lead to the economic and quantitative success of farms (Oosting et al., 2014). According to Manel et al. (2003), genetic discontinuity and correlation between the landscape and barriers imposed by environmental features are key factors for understanding landscape genetics.

The availability of cattle of diverse breeds with great adaptive and productive differences allows breeds to adapt to different environments, management capacities, and markets thus maximizing productivity and profitability. Possibly, the taurine content in composite cattle in (sub) tropical environments may increase over time (Ferraz and Felício, 2010); therefore, Brazilian taurine breeds with their unique adaptations to heat and disease resistance (Boettcher et al., 2015; McManus et al., 2020) should be of interest when climate change is taken into account (Castanheira et al., 2010; Cardoso et al., 2016). Scholtz and Theunissen (2010) reiterated that locally adapted beef cattle breeds should be retained to ensure their continued availability for beef production in the (sub) tropics, due to the variability of their adaptive genes. In addition, national genebanks need to make sure that their sampling strategy is adequate and representative of the genetic variation available within the breed (Blackburn et al., 2017).

Thus, the objective of this study was to explore patterns of spatial genetic structure in cattle breeds locally adapted in Brazil. We aimed to better understand the adaptation and use of cattle breeds in Brazil, as well as acquire knowledge that contributes to conservation efforts.

\section{Materials and Methods}

We sudied 876 individuals belonging to ten cattle breeds (Table 1; Figure 1) raised in Brazil with genomic information from the Genebank of Brazilian Agricultural Research Corporation (Embrapa) and georeferenced in the geographic information system (QGIS 2.4.0 software) and a geographical latitude-longitude projection system (SIRGAS, 2000).

Blood and hair samples were collected from animals from different herds and regions (Table 1) to obtain representative samples, which were divided into five groups: i) all animals; ii) locally adapted taurine breeds (Caracu, Crioulo Lageano, Curraleiro, Mocho Nacional and Pantaneiro); (iii) specialized taurine breeds (Holstein and Jersey); (iv) zebu breeds (Gir, Guzerá 
Table 1 - Sampling sites of cattle breeds in Brazil.

\begin{tabular}{|c|c|c|}
\hline Breed (code) & Location $^{1}$ & $\mathrm{n}^{2}$ \\
\hline & Morrinhos - GO & 18 \\
\hline & Brasilia - DF & 3 \\
\hline & Goiânia - GO & 3 \\
\hline \multirow[t]{5}{*}{ Caracu (CA) } & Conceição da Aparecida - MG & 5 \\
\hline & Passos - MG & 6 \\
\hline & Poços de Caldas - MG & 22 \\
\hline & São Sebastião da Grama - SP & 15 \\
\hline & Uberlândia - MG & 3 \\
\hline \multirow[t]{3}{*}{ Crioulo Lageano (CL) } & Ponte Alta - SC & 100 \\
\hline & Alvorada do Norte - GO & 19 \\
\hline & Brasilia - DF & 12 \\
\hline \multirow{9}{*}{ Curraleiro (CU) } & Nanuque - MG & 1 \\
\hline & Porangatu - GO & 29 \\
\hline & Salto da Divisa - MG & 9 \\
\hline & São João do Piauí - PI & 27 \\
\hline & Alexânia - GO & 16 \\
\hline & $\operatorname{Arcos}-M G$ & 1 \\
\hline & Aurora do Tocantins -TO & 11 \\
\hline & Brasília - DF & 6 \\
\hline & Delta - MG & 1 \\
\hline \multirow{10}{*}{$\mathrm{GIR}$} & Luziânia - GO & 30 \\
\hline & Santa Inês - MA & 23 \\
\hline & Santo Antônio do Descoberto - GO & 1 \\
\hline & São José dos Campos - SP & 2 \\
\hline & São Pedro dos Ferros - MG & 1 \\
\hline & Uberaba - MG & 3 \\
\hline & Vargem Grande do Sul - SP & 2 \\
\hline & Baixo Guandu - ES & 9 \\
\hline & Brasilia - DF & 27 \\
\hline & Curvelo - MG & 1 \\
\hline \multirow[t]{5}{*}{ Guzerá (GUZ) } & Luziânia - GO & 36 \\
\hline & Piraque - TO & 1 \\
\hline & Pradópolis - SP & 1 \\
\hline & Santo Antônio do Descoberto - GO & 11 \\
\hline & São Domingos - GO & 9 \\
\hline \multirow{3}{*}{ Holstein (HOL) } & Brasilia - DF & 52 \\
\hline & Dourados - MS & 13 \\
\hline & Luziânia - GO & 22 \\
\hline \multirow{4}{*}{ Jersey (JER) } & Aurora do Tocantins - TO & 19 \\
\hline & Brasilia - DF & 22 \\
\hline & Delta - MG & 5 \\
\hline & Luziânia - GO & 7 \\
\hline \multirow{4}{*}{ Mocho Nacional (MN) } & Morrinhos - GO & 11 \\
\hline & Brasilia - DF & 11 \\
\hline & Orlândia - SP & 38 \\
\hline & Uberaba - MG & 34 \\
\hline \multirow{6}{*}{ Nelore (NEL) } & Aurora do Tocantins - TO & 14 \\
\hline & Brasilia - DF & 14 \\
\hline & Corumbá - MS & 25 \\
\hline & Delta - MG / ABS PECPLAN & 14 \\
\hline & São Carlos - SP & 9 \\
\hline & Uberaba - MG & 11 \\
\hline \multirow{2}{*}{ Pantaneiro (PAN) } & Corumbá - MS & 84 \\
\hline & Poconé - MT & 10 \\
\hline
\end{tabular}

${ }^{1}$ Municipalities-State; ${ }^{2}$ number of animal.

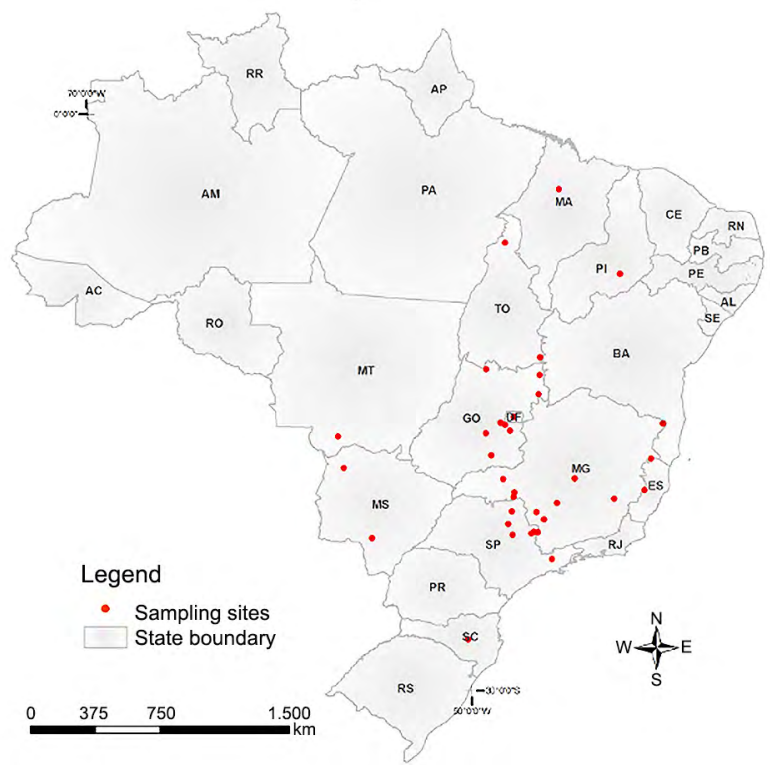

Figure 1 - Sampling points for cattle DNA in Brazil.

and Nelore), and (v) breeds collected close together in the center of the country (Caracu, Curraleiro, Gir and Guzera). Samples from Brasília and Alvorada do Norte included only Curraleiro, as the animals were from the same regions. Other breeds were imported to the conservation herd of Embrapa and were not included.

The genomic DNA was extracted using an inorganic procedure with high saline concentrations and 21 microsatellites were amplified by the polymerase chain reaction $(\mathrm{PCR})$ in five different multiplex systems where the forward primer of each microsatellite was labeled with the fluorochrome according to the expected size of the alleles. The amplified products were electroinjected in an automatic DNA sequencer and the virtual filter D was used for reading the results. An internal standard labeled with Rox (Brondani and Grattapaglia, 2001) was used to predict the allele size. The GeneScan 2.0 and Genotyper 2.1 programs (Applied Biosystems) were used for genotyping the alleles observed (Egito et al., 2007).

We used the Mantel and Spatial autocorrelation tests, implemented by the Alleles In Space program (Miller, 2005). In the Mantel tests, 1,000 randomization repetitions were used to evaluate the significance of the correlations in $\mathrm{P} /(1-\mathrm{P})$, where $\mathrm{P}$ is the proportion of an allele. For the spatial correlation analyses, distances ranged from 5 to 15 classes depending on the number of sampling location in the group to identify distance classes with significantly smaller or larger average genetic distance values than expected values obtained at random. These classes were based on i) equal distances with a different number of animals per class or ii) unequal distances, but equal number of animals per class. A spatial autocorrelation analysis was carried out to test significant correlations between average pairwise genetic distances of haplotypes (Ay) in each spatial class 
defined according to geographical distances among geographical locations (y).

$$
A_{y}=\sum_{i}^{n} \sum_{j>i}^{n}\left(D_{i j} w_{y i j}\right) / \sum_{i}^{n} \sum_{j>i}^{n} w_{y i j}
$$

where: $n$ is the number of individuals in the data set, $D i j$ is the genetic distance between observations $i$ and $j$. Elements of a binary matrix, $w_{y i j}$ take on values of 1 if the geographical distance between observation $i$ and $j$ fall within the boundaries specified for distance class $y$ and are 0 otherwise.

Spatial autocorrelation compares the average genetic distance between pairs of individuals over distance classes and is summarized with the global statistic $V$ which quantifies the heterogeneity of $A_{y}$ values among distance classes.

$$
V=\sqrt{\left(\sum_{y=1}^{z}\left(A_{y}-\bar{D}\right)^{2}\right)} / Z
$$

where: $\bar{D}$ is the average of all pairwise genetic distances for the $z$ individuals in the data set. This is illustrated by a distogram, where $A_{y}$ is 0 when all individuals within distance class y are genetically identical, and 1 when all individuals in distance class y are completely dissimilar.

An allele specific aggregation index for allele $j$, $R j$, is calculated as $R_{j}=\bar{d}_{j}^{O} / \bar{d}_{j}^{E}$ with $\bar{d}_{j}^{O}$ as the average nearest neighbor distance for observations of allele $j$ and $\bar{d}_{j}^{E}$ calculated as $\bar{d}_{j}^{E}=1 / 2 \sqrt{N_{j} / A}$ where: $N_{j}$ is the count of allele $j$ in the sample and $A$ represents the area over which all $n$ sampled individuals in the data set were collected. $\bar{d}_{j}^{E}$ essentially quantifies the expected average nearest neighbor distance of $N_{j}$ randomly distributed alleles over area $A$. Overall, this procedure provides a basis for testing the null hypothesis that each allele is distributed at random in a locus across a landscape (i.e. no aggregation or genetic structure) relative to the aggregation of the actual organisms sampled for analysis purposes. When $A$ is known without error, $R_{j}=1$ if the set of sampled individuals are randomly distributed across the landscape examined. In contrast, $R_{j}<1$ when samples display a clumped or aggregated spatial distribution, and $R_{j}>1$ when samples show a tendency towards a spatially uniform distribution (Pielou, 1977). In addition to performing allele specific tests, Alleles in Space (AIS) also performs a global test by calculating $R_{j}^{A V E}$ over alleles and loci. Similar to the allele specific tests, $p$-values for the global analyses are obtained through the random allocation of individuals and genotypes over the specific set of coordinates sampled. Significance of $R_{j}^{A V E}$ (average allelic aggregation index - a test of nonrandom patterns of spatial genetic diversity) was tested through the use of 1,000 permutations.

The genetic landscape shape was analyzed using residual genetic distances and midpoints of edges derived from Delaunay triangulation. The Alleles in Space program (Miller, 2005) generates three-dimensional genetic landscape surfaces, where the $\mathrm{Z}$-axis (height) represents genetic distance, and the $\mathrm{X}$ and $\mathrm{Y}$-axes represent Universal
Transverse Mercator (UTM) coordinates. This procedure yields an interpolation-based graphical depiction of spatial genetic structure and diversity across landscapes that could be used to identify genetic discontinuities or landscape regions where relatively high or low genetic distances exist. The Monmonier Maximum Difference Algorithm was used to detect geographic barriers due to genetic differences in the data set.

\section{Results}

The Mantel correlations between genetic and geographic distances ranged from 0.02 to 0.18 (Table 2). These correlations were all significant $(p<0.02)$, similar to the spatial autocorrelations. This suggests that the genetic structure could be partially explained by the geographic distance. The mean genetic distance of set pairs from complete data ranged from 0.63 to 0.73 from Spatial Autocorrelation Analyses (Figure 2). The Alleles Specific

Table 2 - Summary of spatial statistics for cattle groups in Brazil.

\begin{tabular}{lccccc}
\hline & Mantel & Autocorrelation & $V$ & $R_{j}$ & $R_{j}^{\text {AVE }}$ \\
\hline All & 0.02 & 0.73 & 0.014 & 0.04 & 0.51 \\
Local Taurine & 0.14 & 0.68 & 0.018 & 0.01 & 0.59 \\
Commercial Taurine & 0.09 & 0.65 & 0.033 & 0.00 & 0.44 \\
Zebu & 0.18 & 0.63 & 0.019 & 0.07 & 0.55 \\
Close & 0.18 & 0.71 & 0.042 & 0.08 & 0.58 \\
\hline
\end{tabular}

$\mathrm{V}=$ variability of Ay among distance classes; $R_{\mathrm{i}}=$ allele specific aggregation index; $R_{i}^{\text {AVE }}=$ average allelic aggregation index.
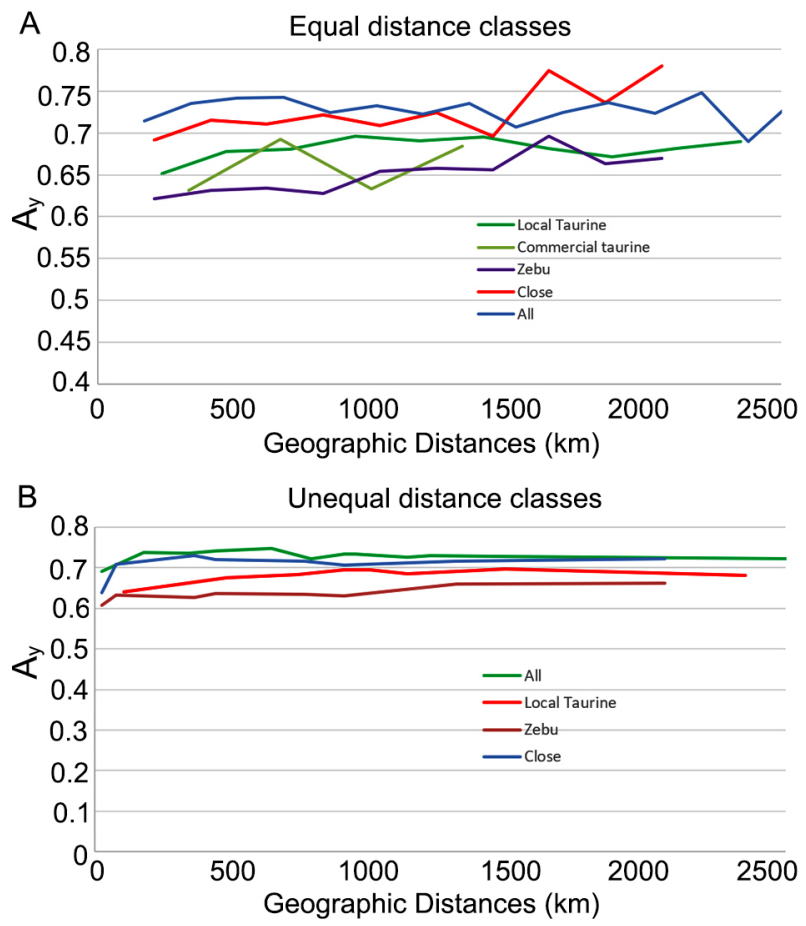

Figure 2 - Distograms for A) Equal and B) Unequal Distance classes for Brazilian cattle breeds 
Aggregation Index $\left(R_{j}\right.$ and $\left.R_{j}^{A V E}\right)$ was higher for locally adapted taurine and zebu breeds as well as the samples of close populations, indicating non-random spatial distribution of the genoptypes in this study.

From the analysis of the complete distogram, global $\mathrm{V}$ ranged from 0.014 to 0.042 and $\mathrm{V}>=$ Vrnd (observed by chance) and was highly significant ( $p<0.001)$, showing the effect of geographic distance on genetic distribution. The distance classes analyzed (Figure 2) presented a clear pattern of genetic discontinuity for cattle breeds in Brazil. This is especially evident with zebu and local taurine breeds. For the latter, genetic differences were seen at geographic distances beyond $899 \mathrm{~km}$, while zebu animals collected at distances greater than $1032 \mathrm{~km}$ were genetically different. Regarding the "close" grouping, geographic distances above $431 \mathrm{~km}$ were significant.

The interpolation of the genetic landscape format is shown in Figure 3, with two perspectives of the same space, where high peaks and valleys represent genetic discontinuities. Monmonier Maximum Difference Algorithms were also used to create Barriers ( $1^{\text {st }}$ - blue , $2^{\text {nd }}-$ light green, $3^{\text {rd }}-$ dark green, $4^{\text {th }}-$ red, $5^{\text {th }}-$ purple) for these discontinuities within each selection group. Therefore, high genetic discontinuities were observed in the Southeast, Midwest and South of the country. These were represented by Pantaneiro in the Midwest, Crioulo Lageano in the South, and Nelore in the Southeast. The highest peaks were seen in the South of the country.

\section{Discussion}

There is growing interest in the use of georeferencing technologies along with genetic information in the management and planning of livestock production systems, as well as predictive adaptive capabilities (Boettcher et al., 2015). The results may be used as criteria to optimize the management of in situ conservation populations and ex situ conservation schemes, as well as in the planning of expansion and adaptation of production systems (Hermuche et al., 2013a, 2013b; Costa et al., 2014). Understanding spatial genetic differences in conservation programs may favor the sampling and adequate representation of populations. According to Miller (2005), the methodology of understanding spatial genetic differences relies on joint analyses of interindividual spatial and genetic information rather than arbitrary groupings of individuals, which is especially important in understanding adaptation profiles.

Most breeds in this study had two or more collection sites in different breeding systems and environments (Table 1). The largest division is between the breeds of the South and Southeast with the Northeastern and Center-Western regions, as seen from the landscape interpolation (Figure 3). While some subdivisions may be evidenced by breed differentiation itself, others may represent breed subdivisions.
Mantel correlations, although significant, were low in all cases, increasing in more specific groups, such as local taurine or zebu. This shows the need for higher sampling of these populations. In terms of geographic and genetic distribution, the Pantaneiro breed was the closest to Curraleiro, as noted in Egito et al. (2007). The Pantaneiro breed has an Association of breeders since 2012; nevertheless, it has not yet been registered to MAPA (Ministry of Agriculture, Livestock and Supply). Thus, the official registration of the breed is important to promote the breed, facilitating and contributing to the dissemination of the genetic material.

In many cases, the introduction of a genetic resource in the past did not necessarily promote economic development and potentially reduced genetic diversity (FAO, 2007). When using a specific genetic resource in a production system, determining breed suitability is necessary, as well as understanding breed adaptability and stability as a component of that system. The selection of imported breeds has frequently been based on partial analyses carried out in more favorable environments where they produce more milk, meat or wool. There is a lack of environmental considerations or lifelong productivity, especially in stressful environments. McManus et al. (2002) showed that locally adapted Pantaneiro cattle had approximately twofold the reproduction rate of Nelore cattle in the environment found in the Brazilian Pantanal. Nelore is considered a thermotolerant breed (Pires et al., 2019); nevertheless, Mattar et al. (2011) showed that phenotype plasticity and genotype expression may be changed along the environmental gradient through selection. In the United States, Blackburn et al. (2017) found ecoregion differences in allele frequencies, mainly between arid and humid regions. The production strategy to be followed in the developing countries of the Southern hemisphere depends mainly on the environment and management level. Zebu or locally adapted breeds (such as Pantaneiro or Curraleiro-Pé Duro), as well as their crossbreds, are viable options under harsh production conditions. As seen here, genetic differentiation exists with a geographic distance of $431 \mathrm{~km}$. This may be attributed to sampling and lack of animal collection covering the whole territory, which was restricted in some populations or because of their limited geographic dispersion or by the geographical extention of Brazil. Therefore, it is important to point out that the focus is on the allele distribution rather than on the breeds themselves.

The Allelic Aggregation Analysis (AAIA) tested for non-random patterns of genetic diversity across the landscape and showed spatial aggregation, deviating from a random distribution. Depending on the environment, different genotypes may respond in different ways. Without environmental stress, the genotypes of highly productive and selected breeds can express themselves. In adverse environments, animals selected or adapted to fitness traits, which were overlooked by breeders in the 

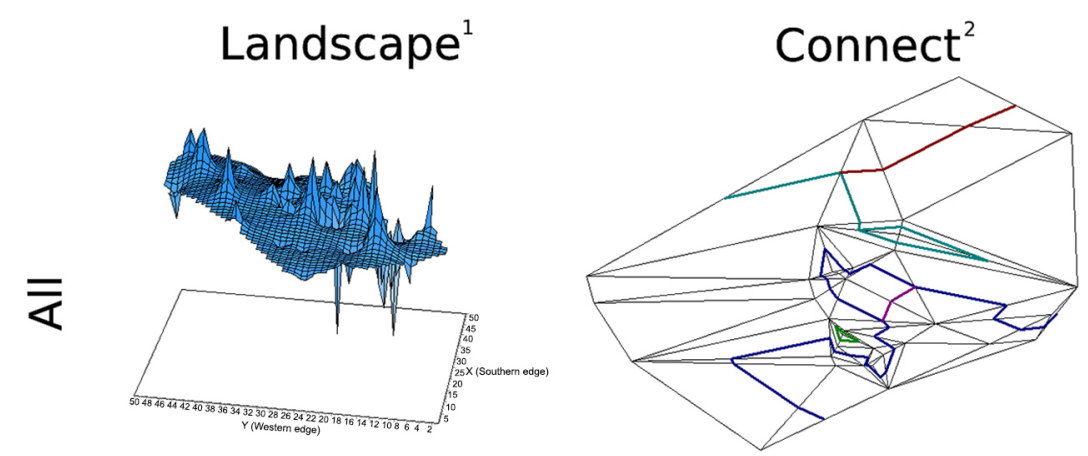

Collection $^{3}$
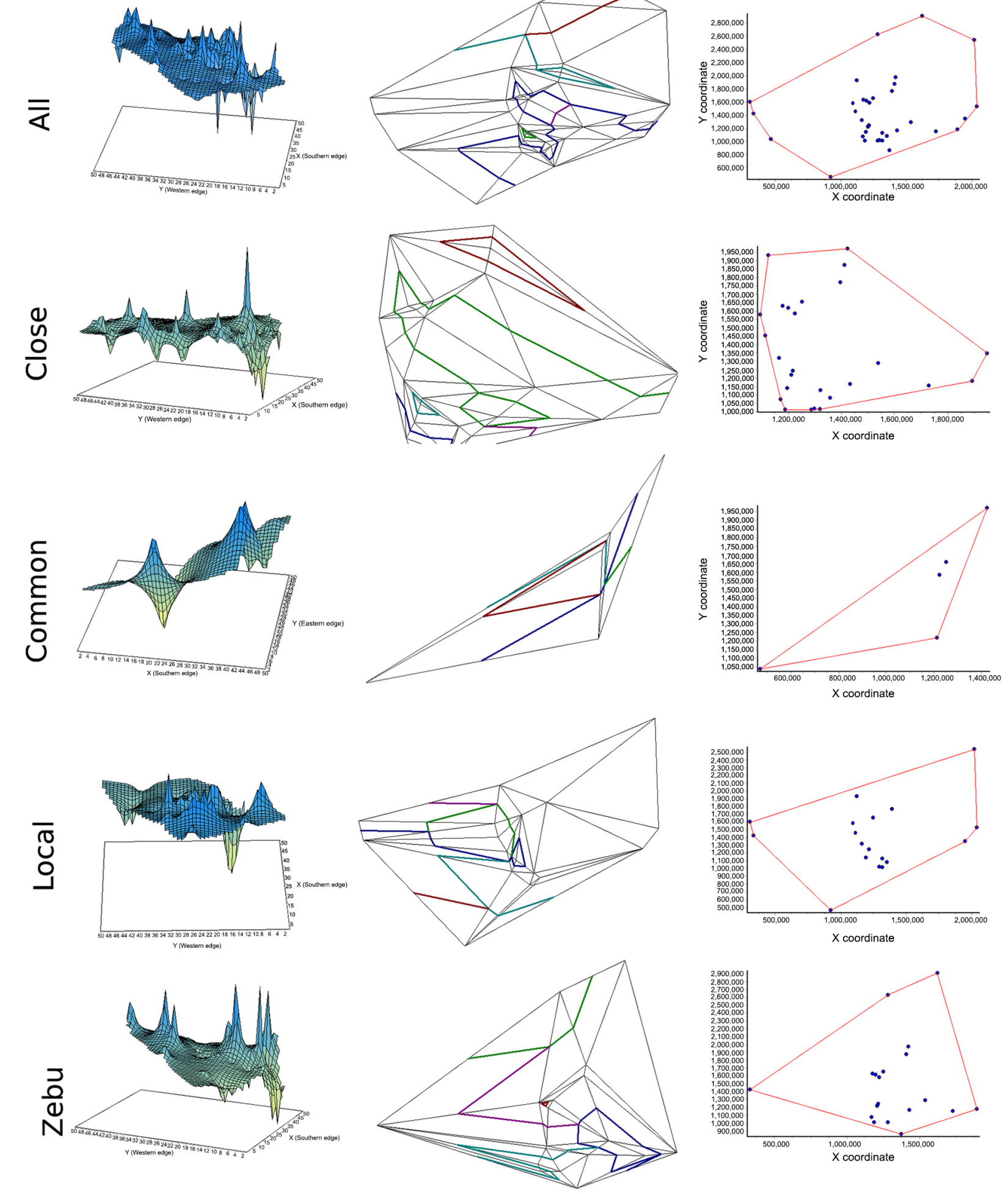

Figure 3 - Genetic landscape space and Monmonier Maximum Difference Barriers for cattle breeds in Brazil. ${ }^{1}$ Genetic landscape space; ${ }^{2}$ Connectivity Networks and Barriers from Monmonier Maximum Difference Algorithm, Barriers: $1^{\text {st. }}-$ blue, $2^{\text {nd. }}-$ light green, $3^{\text {rd. }}-$ dark green, $4^{\text {th. }}-$ red, $5^{\text {th. }}-$ purple; ${ }^{3}$ Collection Points. 
past, could produce better. These characteristics include challenges to ticks, internal parasites, low quality forage, and highly variable nutrition in terms of quantity or quality as well as environmental temperature (McManus et al., 2009).

Mocho Nacional (MN) animals are registered to the Caracu breeders association because of their phenotypic similarity, except that the Mocho National is polled (McManus et al., 2005). The similarity between breeds was also noted in the present study. This may lead to a lack of genetic differentiation between collection points, as seen in the "close" group. The Caracu and Gir may have been crossed at some time with MN to create polled animals. The MN breed had a direct influence on the formation of polled zebu, such as Tabapuã and the polled varieties of the Gir and Nelore breeds (Mariante and Cavalcante, 2006).

The establishment of an economically viable breeding system in a given region requires the choice of breeds or varieties that are appropriate to local environmental conditions. A common theme for many arguments for genetic conservation is resistance to disease, because it affects conservation in many ways. Genetic resources that require conservation are often those with great variability of adaptation to diseases or inhospitable environments (Groeneveld et al., 2016). The size of the population individually is a risk, mainly when considering diseases to which the population is not resistant. Agrobiodiversity is a critical component of global biodiversity. More than $75 \%$ of world food production is produced by just over 25 domestic species of plants and animals. Strategies to ensure agrobiodiversity are necessary, such as species substitution (Seo and Mendelsohn, 2008) or shifting from Bos taurus to Bos indicus (Hoffmann, 2010). The handling and management of these resources are essential to ensure food security. On the other hand, the pressure to increase productivity and sustainability of production systems is intense and increasing. As seen here, zebu cattle also show genetic differences across geographical distances; therefore, conservation efforts should not be limited to locally adapted breeds (Krehbiel et al., 2019; Paim et al., 2019).

It may be useful to assess local adaptation and the effects of selection carried out by humans (Manel et al., 2010). As gene flow in animals is influenced mainly by anthropic factors (Anderson et al., 2010), breed distribution is the result of the selection of the most desired individuals, adaptation to different environments and demographic effects, such as domestication and migration (Bruford et al., 2003). In the results shown here, locally adapted breeds are distributed regionally with high genetic differentiation at short distances, which causes confusion in the evaluation of the results observed. This may be due to a lack of movement of animals between localities due to deficiencies in infrastructure, especially in the Northeastern regions, where farms tend to be isolated and with a small herd size (Lôbo et al., 2011).
Another point to be considered is that, until recently, these breeds had little market value and thus there was little interchange between different farms, animlas were used only for family or regional consumption. All breeds adapted to local conditions are genetically close because they had their origin in the Iberian Peninsula therefore there is little difference between them due to similarity in their initial origin (Martínez et al., 2012). There is a possibility of miscegenation between these breeds when they arrived in the Brazil and there was no distinction between the different breeds (the breed concept came much later). Herd expansion in the different Brazilian habitats and consolidation of these populations that arrived with Portuguese colonizers led to the differentiation of herds, but with several common alleles. It was therefore possible to differentiate breeds adapted to local conditions from other taurines (Egito et al., 2007), demonstrating their genetic similarity.

The genetic differentiation found in this study was only detected at distances beyond $431 \mathrm{~km}$. Short geographical distances may be due to rearing in family farming systems and close herds. This creates differentiation between animals of the same breed, precisely by the genetic drift. In Curraleiro, this is very evident by the number of populations sampled. Microsatellites showed which populations exchange animals and are genetically closer and which are more distinct, although they are in the same Brazilian state (Egito et al., 2007). Microsatellites also demonstrate similarity between two populations reared in different states but with the same farm owner. Several farmers are not aware of other farmers who still breed these breeds adapted to local conditions, except for Caracu. Breeding and reproduction of these animals are restricted to the individual farm. In Curraleiro, Silva Filho et al. (2014) suggested the need to exchange animals between different herds to increase variability within the breed. Studies of these populations with Single Nucelotide Polymorphisms (SNPs) may help to elucidade further patterns of genetc patterns in these breeds, but genetic diversity was similar in Campos et al. (2017) using SNPs and Egito et al. (2007) using microsatelite markers. Neither of these studies took into account geographical distributions; however, information from SNPs and functional genomics may help understand the breed adaptation to harsh environments (McManus et al., 2020).

In more developed areas, where management skills may be better, but conditions are often inhospitable, with relatively low levels of natural nutrition, crossbreeding with small framed cows may increase production of beef cattle, such as creole or locally adapted breeds (Leroy et al., 2016). Ferraz and Felício (2010) show that several options are available in rearing cattle breeds in Brazilian systems, especially due to demands from climate change. Studies on animal production worldwide have suggested a need to replace breeds and species in production systems (Dumont et al., 2014). However, others argue that this may not be necessary (Blackburn et al., 2017), suggesting 
the creation of custom selection indices that could more closely match genotypes to the environments where they perform (Cole and VanRaden, 2018). Nevertheless, breeds adapted to local conditions have specific traits for heat tolerance and disease resistance (Ferraz and Felício, 2010). Studies have shown that these breeds have improved traits over Nelore (Carvalho et al., 2017; Cardoso et al., 2016). The maintenance of genetic variability is therefore important for the success of future breeding programs, both for conservation and commerical breeds. Sampling for genebanks therefore needs to be consistent with breed distribution and variability (Blackburn et al., 2017).

\section{Conclusions}

This study shows the need to increase sampling of cattle for conservation purposes in Brazil. Landscape genetic statistics show a low, but significant effect of geographic features on genetic distances. These results could be used in sampling for conservation efforts, not only of beeds adapted to local conditions, but also commercial breeds. Wider sampling is needed for both breeds and environmental conditions.

\section{Acknowledgements}

The authors are thankful for the financial assistance from Brazilian Agricultural Research Corporation (Embrapa) - Beef Cattle and Brazilian Agricultural Research Corporation (Embrapa) - Genetic Resources and Biotechnology; Coordination for the Improvement of Higher Level Personnel (CAPES), Brazil; and Brazilian National Council for Scientific and Technological Development (CNPq), Brazil.

\section{Authors' Contributions}

Conceptualization: Souza, A.C.B; Egito, A.A.; McManus, C. Data acquisition: Souza, A.C.B; Egito, A.A.; McManus, C. Data analysis: McManus, C. Design of methodology: Souza, A.C.B; Egito, A.A.; McManus, C. Writing and editing: Souza, A.C.B; Egito, A.A.; Peripolli, V.; McManus, C.

\section{References}

Anderson, C.D.; Epperson, B.K.; Fortin, M.; Holderegger, R.; James, P.M.A.; Rosenberg, M.S.; Scribner, K.T.; Spear, S. 2010. Considering spatial and temporal scale in landscape-genetic studies of gene flow. Molecular Ecology 19: 3565-3575.

Antonini, A.; Argilés-Bosch, J.M. 2017. Productivity and environmental costs from intensification of farming. A panel data analysis across EU regions. Journal of Cleaner Production 140: 796-803

Blackburn, H.D.; Krehbiel, B.; Ericsson, S.A.; Wilson, C.; Caetano, A.R.; Paiva, S.R. 2017. A fine structure genetic analysis evaluating ecoregional adaptability of a Bos taurus breed (Hereford). PLoS ONE 12: e0176474.
Boettcher, P.J.; Hoffmann, I.; Baumung, R.; Drucker, A.G.; McManus, C.; Berg, P.; Stella, A.; Nilsen, L.B.; Moran, D.; Naves, M.; Thompson, M.C. 2015. Genetic resources and genomics for adaptation of livestock to climate change. Frontiers in Genetics 5: 461.

Brondani, R.P.; Grattapaglia, D. 2001. Cost-effective method to synthesise a fluorescent internal DNA standard for automated fragment sizing. Biotechniques 31: 793-800.

Bruford, M.W.; Bradley, D.G.; Luikart, G. 2003. DNA markers reveal the complexity of livestock domestication. Nature 4: 900-910.

Campos, B.M.; Carmo, A.S.; Egito, A.A.; Mariante, A.S.; Albuquerque, M.S.M.; Gouveia, J.J.S.; Malhado, C.H.M.; Verardo, L.L.; Silva, M.V.G.B.; Carneiro, P.L.S. 2017. Genetic diversity, population structure, and correlations between locally adapted zebu and taurine breeds in Brazil using SNP markers. Tropical Animal Health and Production 49: 16771684.

Cardoso, C.C.; Lima, F.G.; Fioravanti, M.C.S.; Egito, A.A.; Silva, F.C.P.; Tanure, C.B.; Peripolli, V.; McManus, C. 2016. Heat tolerance in Curraleiro Pe-Duro, Pantaneiro and Nelore cattle using thermographic images. Animals 6: 2-11.

Carvalho, G.M.C.; Frota, M.N.L.; Lima Neto, A.F.; Azevêdo, D.M.M.R.; Araujo Neto, R.B.; Araujo, A.M.; Pereira, E.S.; Carneiro, M.S.S. 2017. Live weight, carcass, and meat evaluation of Nellore, Curraleiro Pé-Duro, and their crossbred products in Piauí State. Revista Brasileira de Zootecnia 46: 393-399.

Castanheira, M.; Paiva, S.R.; Louvandini, H.; Landim, A.; Fiorvanti, M.C.S.; Dallago, B.S.; Correa, P.S.; McManus, C. 2010. Use of heat tolerance traits in discriminating between groups of sheep in central Brazil. Tropical Animal Health and Production 42: 1821-1828.

Costa, N.S.; Hermuche, P.; Cobuci, J.A.; Guimarães, R.F.; Carvalho Júnior, O.A.; Costa, C.N.; Gomes, R.A.T.; McManus, C.M. 2014. Georeferenced evaluation of genetic breeding value patterns in Brazilian Holstein cattle. Genetics and Molecular Research 13: 9806-9816.

Dumont, B.; González-García, E.; Thomas, M.; Fortun-Lamothe, L.; Ducrot, C.; Dourmad, J.Y.; Tichit, M. 2014. Forty research issues for the redesign of animal production systems in the 21st century. Animal 8: 1382-1393.

Egito, A.A.; Paiva, S.R.; Albuquerque, M.S.M.; Mariante, A.S.; Almeida, L.D.; Castro, S.R.; Grattapaglia, D. 2007. Microsatellite based genetic diversity and relationships among ten Creole and commercial cattle breeds raised in Brazil. BMC Genetics 8: 1-14.

Fenderson, L.E.; Kovach, A.I.; Llamas, B. 2020. Spatiotemporal landscape genetics: investigating ecology and evolution through space and time. Molecular Ecology 29: 2018-246.

Ferraz, J.B.S.; Felício, P.E. 2010. Production systems: an example from Brazil. Meat Science 84: 238-243.

Food and Agriculture Organization [FAO]. 2007. The State of the World's Animal Genetic Resources for Food and Agriculture. FAO, Rome, Italy.

Groeneveld, L.F.; Gregusson, S.; Guldbrandtsen, B.; Hiemstra, S.J.; Hveem, K.; Kantanen, J.; Lohi, H.; Stroemstedt, L.; Berg, P. 2016. Domesticated Animal Biobanking: Land of Opportunity. PLoS Biology 14: e1002523. 
Hermuche, P.; Maranhão, R.L.A.; Guimarães, R.F.; Carvalho Júnior, O.A.; Gomes, R.A.T.; Paiva, S.R.; McManus, C.M. 2013a. Dynamics of sheep production in Brazil. ISPRS International Journal of Geo-Information 2: 665-679.

Hermuche, P.; Guimarães, R.F.; Carvalho Júnior, O.A.; Paiva, S.R.; Gomes, R.A.T.; McManus, C.M. 2013b. Environmental factors that affect sheep production in Brazil. Applied Geography 44: 172-181.

Hoffmann, I. 2010. Climate change and the characterization, breeding, and conservation of animal genetic resources. Animal Genetics 41: 32-46.

Joost, S.; Colli, L.; Baret, P.V.; Garcia, J.F.; Boettcher, P.J.; Tixier-Boichard, M.; Ajmone-Marsan, P.; Globaldiv, C. 2010. Integrating geo-referenced multiscale and multidisciplinary data for the management of biodiversity in livestock genetic resources. Animal Genetics 41: 47-63.

Krehbiel, B.C.; Thomas, M.G.; Wilson, C.S.; Speidel, S.E.; Enns, M.R.; Paiva, S.R.; Blackburn, H.D. 2019. Evaluation of genetic structure across U.S. climate zones using prominent AI sires of Red Angus cattle. Livestock Science 225: 26-31.

Leroy, G.; Baumung, R.; Boettcher, P.; Scherf, B.; Hoffmann, I. 2016. Review: sustainability of crossbreeding in developing countries; definitely not like crossing a meadow. Animal 10: 262-273.

Lôbo, R.N.B.; Pereira, I.D.C.; Facó, O.; McManus, C.M. 2011. Economic values for production traits of Morada Nova meat sheep in a pasture based production system in semi-arid Brazil. Small Ruminant Research 96: 93-100.

Manel, S.; Joost, S.; Epperson, B.K.; Holderegger, R.; Storfer, A.; Rosenberg, M.S.; Scribner, K.T.; Bonin, A.; Fortin, M. 2010. Perspectives on the use of landscape genetics to detect genetic adaptive variation in the field. Molecular Ecology 19: 37603772 .

Manel, S.; Schwartz, M.K.; Luikart, G.; Taberlet, P. 2003. Landscape genetics: combining landscape ecology and population genetics. Trends in Ecology \& Evolution 18: 189197.

Mariante, A.S.; Cavalcante, E.N. 2006. Animals of Discovery: Domestic Breeds of Brazilian History $=$ Animais do Descobrimento: Raças Domésticas da História do Brasil. Embrapa Recursos Genéticos e Biotecnologia, Brasília, DF, Brazil (in Portuguese).

Martínez, A.M.; Gama, L.T.; Cañón, J.; Ginja, C.; Delgado, J.V.; Dunner, S.; Landi, V.; Martín-Burriel, I.; Penedo, M.C.; Rodellar, C.; Vega-Pla, J.L.; Acosta, A.; Alvarez, L.A.; Camacho, E.; Cortés, O.; Marques, J.R.; Martínez, R.; Martínez, R.D.; Melucci, L.; Martínez-Velázquez, G.; Muñoz, J.E.; Postiglioni, A.; Quiroz, J.; Sponenberg, P.; Uffo, O.; Villalobos, A.; Zambrano, D.; Zaragoza, P. 2012. Genetic footprints of Iberian cattle in America 500 years after the arrival of Columbus. PLoS One 7: e49066.
Mattar, M.; Silva, L.; Alencar, M.; Cardoso, F. 2011. Genotype X environment interaction for long-yearling weight in Canchim cattle quantified by reaction norm analysis. Journal of Animal Science 89: 2349-2355.

McManus, C.; Abreu, U.G.P.; Lara, M.A.C.; Sereno, J.R.B. 2002. Genetic and environmental factors which influence weight and reproduction parameters in pantaneiro cattle in Brazil. Archivos de Zootecnia 51: 91-97.

McManus, C.M.; Faria, D.A.; Bem, A.; Maranhão, A.Q.; Paiva, S.R. 2020. Physiology and genetics of heat stress in cattle. CAB Reviews 15: 018.

McManus, C.M.; Paludo, G.R.; Louvandini, H.; Gugel, R.; Sasaki, L.C.B.; Paiva, S.R. 2009. Heat tolerance in Brazilian sheep: physiological and blood parameters. Tropical Animal Health and Production 9: 95-101.

McManus, C.M.; Ribeiro, R.S.; Mariante, A.S.; Egito, A.A.; Louvandini, H.; Paiva, S.R. 2005. Production aspects of a herd of Mocho Nacional breed. Archivos de Zootecnia 54: 459-464.

Miller, M.P. 2005. Alleles In Space (AIS): computer software for the joint analysis of interindividual spatial and genetic information. Journal of Heredity 96: 722-724.

Oosting, S.J.; Udo, H.M.J.; Viets, T.C. 2014. Development of livestock production in the tropics: farm and farmers' perspectives. Animal 8: 1238-1248.

Paim, T.P.; Faria, D.A.; Hay, E.H.; McManus, C.; Lanari, M.R.; Esquivel, L.C.; Cascante, M.I.; Alfaro, E.J.; Mendez, A.; Faco, O.; Silva, K.M.; Mezzadra, C.A.; Mariante, A.; Paiva, S.R.; Blackburn, H.D. 2019. New world goat populations: a genetically diverse reservoir for future use. Scientific Reports 9: 1476.

Pires, B.V.; Stafuzza, N.B.; Lima, S.B.G.P.N.P.; Negrão, J.A.; Paz, C.C.P. 2019. Differential expression of heat shock protein genes associated with heat stress in Nelore and Caracu beef cattle. Livestock Science 230: e103839.

Scholtz, M.M.; Theunissen, A. 2010. The use of indigenous cattle in terminal crossbreeding to improve beef cattle production in Sub-Saharan Africa. Animal Genetic Resources 46: 33-39.

Seo, S.N.; Mendelsohn, R. 2008. Measuring impacts and adaptation to climate change: a structural Ricardian model of African livestock management. Agricultural Economics 38: 151-165.

Silva Filho, E.; Silva, M.H.; Campelo, J.E.G.; Derosia, M.R.; Pinheiro, L.M.L.; Almeida, M.J.O. 2014. Genetic characterization of Curraleiro Pé-Duro bovine breed from a conservation herd of Brazilian semiarid. Genetics and Molecular Research 13: 2149-2154.

Storfer, A.; Murphy, M.A.; Spear, S.F.; Holderegger, R.; Waits, L.P. 2010. Landscape genetics: where are we now? Molecular Ecology 19: 3496-3514. 